OPEN ACCESS

Edited by:

Markus Y. Mapara, Columbia University, United States

Reviewed by:

Benny J. Chen,

Duke University, United States

Federico Simonetta,

Geneva University Hospitals (HUG),

Switzerland

*Correspondence:

Hanyun Ren

renhy0813@163.com

Yujun Dong

dongy@hsc.pku.edu.cn

${ }^{\dagger}$ These authors have contributed equally to this work

Specialty section:

This article was submitted to Alloimmunity and Transplantation,

a section of the journal

Frontiers in Immunology

Received: 30 December 2020 Accepted: 11 June 2021

Published: 28 June 2021

Citation:

Liu H, Yu Z, Tang B, Miao S, Qin C,

Li Y, Liang Z, Shi Y, Zhang Y, Wang Q,

Yan $M$, Song $Z$, Ren $H$ and Dong $Y$ (2021) LYG1 Deficiency Attenuates the

Severity of Acute Graft-Versus-Host Disease via Skewing Allogeneic T Cells

Polarization Towards Treg Cells.

Front. Immunol. 12:647894.

doi: 10.3389/fimmu.2021.647894

\section{LYG1 Deficiency Attenuates the Severity of Acute Graft-Versus-Host Disease via Skewing Allogeneic T Cells Polarization Towards Treg Cells}

\author{
Huihui Liu ${ }^{\dagger}$, Zhengyu $\mathrm{Yu}^{\dagger}$, Bo Tang, Shengchao Miao, Chenchen Qin, Yuan Li, \\ Zeyin Liang, Yongjin Shi, Yang Zhang, Qingya Wang, Miao Yan, Zhengyang Song, \\ Hanyun Ren ${ }^{*}$ and Yujun Dong ${ }^{*}$ \\ Department of Hematology, Peking University First Hospital, Beijing, China
}

Acute graft-versus-host disease (aGVHD) is a lethal complication after allogeneic hematopoietic stem cell transplantation. The mechanism involves the recognition of host antigens by donor-derived $T$ cells which induces augmented response of alloreactive $T$ cells. In this study, we characterized the role of a previously identified novel classical secretory protein with antitumor function-LYG1 (Lysozyme G-like 1), in aGVHD. LYG1 deficiency reduced the activation of $\mathrm{CD}^{+} \mathrm{T}$ cells and Th1 ratio, but increased Treg ratio in vitro by MLR assay. By using major MHC mismatched aGVHD model, LYG1 deficiency in donor T cells or $\mathrm{CD}^{+}{ }^{+} \mathrm{T}$ cells attenuated aGVHD severity, inhibited $\mathrm{CD}^{+} \mathrm{T}$ cells activation and IFN- $\gamma$ expression, promoted FoxP3 expression, suppressed CXCL9 and CXCL10 expression, restrained allogeneic CD4 ${ }^{+} T$ cells infiltrating in target organs. The function of LYG1 in aGVHD was also confirmed using haploidentical transplant model. Furthermore, administration of recombinant human LYG1 protein intraperitoneally aggravated aGVHD by promoting IFN- $\gamma$ production and inhibiting FoxP3 expression. The effect of rhLYG1 could partially be abrogated with the absence of IFN- $\gamma$. Furthermore, LYG1 deficiency in donor T cells preserved graft-versus-tumor response. In summary, our results indicate LYG1 regulates aGVHD by the alloreactivity of $\mathrm{CD}^{+} \mathrm{T}$ cells and the balance of Th1 and Treg differentiation of allogeneic CD4 ${ }^{+} \mathrm{T}$ cells, targeting LYG1 maybe a novel therapeutic strategy for preventing aGVHD.

Keywords: LYG1, aGVHD, allogeneic CD4+ $\mathrm{T}$ cells, alloreactivity, Th1 cells, Treg cells

Abbreviations: aGVHD, acute graft-versus-host disease; allo-HSCT, allogeneic allogeneic hematopoietic cell transplantation; BM, Bone marrow cells; Treg, Regulatory T cells; Th1, T helper 1 cells; Tc1, T cytotoxic 1 cells; rhLYG1, recombinant human LYG1 protein; LYG1, Lysozyme G-like 1; MLR, mixed lymphocyte reaction; TBI, total body irradiation; GVT, graftversus-tumor. 


\section{INTRODUCTION}

Acute graft-versus-host disease (aGVHD) is medical complication which mainly destroy host tissues including the skin, liver, colon and the lung after allogeneic hematopoietic cell transplantation (allo-HSCT), representing a major cause for morbidity and non-relapse mortality $(1,2)$. Alloreactive $\mathrm{T}$ cells were the major detrimental factors during the pathogenesis of aGVHD $(3,4)$. In GVHD, the donor $\mathrm{T}$ cells recognize the host antigens, activate, differentiate and traffic to the target organs under guidance of cytokines and chemokines, and result in inflammatory damages in the target organs (5). IFN- $\gamma$ is a central regulatory cytokine in the initiation and maintenance of aGVHD due to its crucial function for $\mathrm{CD}^{+}$Th1 cells differentiation and $\mathrm{CD} 8^{+} \mathrm{T}$ cells function during the priming and expansion phase (6). Regulatory T cells (Treg) which reduces the incidence and severity of aGVHD is one of the protective factors against aGVHD (7). Due to the inhibitory characteristics, Treg cells have been widely studied for GVHD treatment in preclinical models and clinical trials $(8,9)$.

Despite considerable achievements in the treatment of aGVHD, it remains a major clinical problem for the patients undergoing allo-HSCT. Approximately $40 \%-60 \%$ of recipients will develop aGVHD, imposing crucial risks for long term survival (10). Because the success of allo-HSCT relies on graftversus-tumor (GVT) function mediated by $\mathrm{T}$ cells, immunosuppressive strategies are less attractive (5). Therefore, explorations on new mechanisms and novel therapeutic strategies for aGVHD with preserving GVT responses are important and necessary.

In our previous study, we have identified and characterized a novel classical secretory protein LYG1 (Lysozyme G-like 1) through immunogenomics strategy (11). Recombinant human LYG1 protein (rhLYG1) can inhibit tumor growth by promoting the activation and IFN- $\gamma$ production of tumor antigen-specific $\mathrm{CD}^{+} \mathrm{T}$ cells (11). While LYG1 deficiency accelerated B16 and LLC1 tumor growth due to the inhibited T cell functions. However, the function of LYG1 in other immune diseases is unclear.

Given the enhanced $\mathrm{T}$ cell functions under rhLYG1 stimulation and the inhibited $\mathrm{T}$ cell functions with LYG1 deficiency, we hypothesized that LYG1 might participate in the development of GVHD. To verify the hypothesis, we explored the role and mechanisms of LYG1 during GVHD using aGVHD murine models in this study.

\section{MATERIALS AND METHODS}

\section{Mice}

Six- to eight-week-old C57BL/6 (B6, H2Kb) and BALB/c (H2Kd) and $(\mathrm{B} 6 \times \mathrm{DBA} / 2) \mathrm{F} 1(\mathrm{BDF} 1, \mathrm{H}-2 \mathrm{~b}-\mathrm{d})$ mice were purchased from Vital River Laboratories. The Lygl conventional knockout mice (C57BL/6 background, $L y g 1^{-/}$) were generous gifts from Prof. Wenling Han at Peking University Health Science Center (Beijing, China). IFN- $\gamma^{-/}$mice (B6.129S7-IFNgtm1Ts/J) were purchased from the Model Animal Research Center of Nanjing
University. Homozygous knockout $\left(\mathrm{Lygl}^{-/}\right)$and the littermate wild-type (WT, $L y g 1^{+/+}$) mice were used for all related experiments. All mice were bred at the center animal laboratory of Peking University First Hospital under specific pathogen-free conditions, and all experiments were approved by the Ethics Committee of Peking University First Hospital.

\section{Mixed Lymphocyte Reaction (MLR)}

Splenocytes derived from BALB/c mice were used as stimulator cells. $\mathrm{CD}^{+} \mathrm{T}$ cells were used as responder cells selected from splenocytes of $L y g 1^{+/+}$or $L y g 1^{-/-}$mice using Mouse $\mathrm{CD}^{+} \mathrm{T}$ cell isolation kit (Biolegend, San Diego, US) according to the manufacturer's instructions. The purity of $\mathrm{CD}^{+} \mathrm{T}$ cell was $>90 \%$ assessed by flow cytometry. The responder cells $(2 \times$ $10^{5}$ in $100 \mu \mathrm{l}$ complete culture medium) labeled by CFSE were cultured with stimulator cells treated with mitomycin C (Selleck, Houston, US) for 30 minutes $\left(5 \times 10^{5}\right.$ in $100 \mu \mathrm{l}$ complete culture medium) in 96 well plate. After 5 days of culture, the cells were analyzed by flow cytometry.

\section{aGVHD Mouse Model}

Bone marrow cells (BM) were collected by red blood cell lysis. Splenocytes were isolated by Ficoll gradient centrifugation. $\mathrm{CD}^{+}$, $\mathrm{CD}^{+}$and $\mathrm{CD}^{+} \mathrm{T}$ cells were sorted from splenocytes of $\mathrm{Lyg} 1^{+/+}$or $\mathrm{Lygl}^{-/}$mice using Mouse $\mathrm{CD}^{+}, \mathrm{CD}^{+}$and $\mathrm{CD}^{+} \mathrm{T}$ cell isolation kit (Biolegend, San Diego, US) according to the manufacturer's instructions. The purities were $>90 \%$ assessed by flow cytometry. Recipient (BALB/c, H2Kd) mice were conditioned with total body irradiation (TBI) at $750 \mathrm{cGy}$ (60 Co $\gamma$ source) on day 0 followed by allogeneic transplantation intravenously: $5 \times 10^{6} \mathrm{Lygl}^{+/+} \mathrm{B} 6 \mathrm{BM}$ $(\mathrm{H} 2 \mathrm{~Kb})$ and $3 \times 10^{6} \mathrm{CD}^{+} \mathrm{T}$ cells (or $1.8 \times 10^{6} \mathrm{CD}^{+} \mathrm{T}$ cells or $1.8 \times 10^{6} \mathrm{CD}^{+} \mathrm{T}$ cells) from $\mathrm{Lyg} 1^{+/+}$or $L y g 1^{-/}$splenocytes $(\mathrm{H} 2 \mathrm{~Kb})$ (12). BM control group were given $5 \times 10^{6} \mathrm{Lygl}^{+/+} \mathrm{B} 6 \mathrm{BM}$ alone. Syngeneic transplant group (Syn) were given $5 \times 10^{6} \mathrm{BM}(\mathrm{H} 2 \mathrm{~Kb})$ and $3 \times 10^{6} \mathrm{CD}^{+} \mathrm{T}$ cells sorting from BALB/c splenocytes $(\mathrm{H} 2 \mathrm{Kd})$. Haploidentical $(\mathrm{B} 6 \rightarrow \mathrm{BDF} 1)$ transplant model (HaploHSCT): recipient $((\mathrm{B} 6 \times \mathrm{DBA} / 2) \mathrm{F} 1(\mathrm{BDF} 1, \mathrm{H}-2 \mathrm{~b}-\mathrm{d}))$ mice were conditioned with TBI at $900 \mathrm{cGy}$ on day 0 followed by allogeneic transplantation intravenously: $5 \times 10^{6} L y g 1^{+/+} \mathrm{B} 6 \mathrm{BM}(\mathrm{H} 2 \mathrm{~Kb})$ and $2 \times 10^{7}$ cells from $L y g 1^{+/+}$or $L y g 1^{-/-}$splenocytes $(\mathrm{H} 2 \mathrm{~Kb})(13)$. For the experiments using rhLYG1 administration, recipient (BALB/c, H2Kd) mice were conditioned with TBI at $750 \mathrm{cGy}$ on day 0 followed by allogeneic transplantation intravenously: $5 \times 10^{6}$ B6 BM $(\mathrm{H} 2 \mathrm{~Kb})$ and $3 \times 10^{6} \mathrm{CD}^{+} \mathrm{B} 6$ or IFN- $\gamma^{--} \mathrm{T}$ cells $(\mathrm{H} 2 \mathrm{~Kb})$. rhLYG1 were injected intraperitoneally in BALB/c recipients daily from day 1 to 7 after transplantation. Survival was monitored every day, recipient's weight and GVHD score were measured every week. The scoring system to evaluate the severity of aGVHD includes five clinical parameters: weight, activity, skin, fur ruffling, and posture. Individual mice were scored 0-2 for each criterion (14). Representative tissues of aGVHD target organs (liver and lung) were excised from recipients on 28 days after transplantation and subjected to histopathological scoring $(15,16)$. Immunohistochemical (IHC) analysis for CD4+ and CD8+ (servicebio, China) were performed on the tissues of recipient mice at 7 days post-transplantation according to the manufacturer's instructions. 


\section{GVT Mouse Model}

$2.5 \times 10^{4}$ mouse mastocytoma cell strain P815 (H2Kd) were injected intravenously into per aGVHD recipient on day 0 after allogeneic transplantation. Survival was monitored every day. The P815 was retrovirally transduced with a luc/neo plasmid using a protocol described previously (17). Mice that received P815-luc/neo were given intraperitoneal $(200 \mathrm{mg} / \mathrm{kg}$ ) D-Luciferin (Xenogen, Alameda, $\mathrm{CA}$ ) and placed supine in the Xenogen IVIS bioluminescence imaging system under anesthesia with isofluorane. Pseudocolor images showing whole-body distribution of bioluminescent signal were superimposed on conventional grayscale photographs. Livers were excised from recipients died or 14 days after transplantation and tumor burden on the livers were analyzed.

\section{Isolation of Cells and Flow Cytometry}

Flow cytometry was performed using the following anti-mouse antibodies from Biolegend (Cal., US): H2Kb-FITC, CD3-APC/Cy7, CD4-PE/cy7, CD8-BV421, IFN- $\gamma$-PE, CD69-PE, CD44-FITC, CD62L-APC, T-bet-FITC. Spleens, livers and lungs were excised on day 7 after transplantation. Spleens and livers gently pressed through a cell strainer $(70 \mu \mathrm{m})$. Livers infiltrating lymphocytes were isolated using Percoll (Living, Beijing, China). Perfused lungs were digested in RPMI-1640 medium containing type IV bovine pancreatic DNase (30 mg/ml; Sigma-Aldrich, US) and collagenase XI ( $0.7 \mathrm{mg} / \mathrm{ml}$; Sigma-Aldrich, US) to obtain single-cell suspensions. Single-cell suspensions prepared from the above operation were kept on ice and blocked by incubation with anti-Fc receptor antibody. For membrane molecule analysis, cells were labeled with fluorescent conjugated antibodies at $4^{\circ} \mathrm{C}$ for 30 minutes followed by washes with cold PBS. For cytokine analysis, cells were stimulated with Cell Activation Cocktail (with Brefeldin A) (Biolegend, Cal., US) for 6 hours before cells were harvested for analysis. Cells were first stained with surface markers and then fixed and permeabilized with BD IntraSure Kit (BD Biosciences, NJ, US) according to the manufacturer's instructions for intracellular staining. Foxp3 and T-bet were stained using a Foxp3 Fix/Perm Buffer Set (Biolegend, Cal., US), according to the manufacturer's instructions. Flow cytometry analysis was performed on FACS Canto II (BD Biosciences, NJ, US) and analyzed with FlowJo software.

\section{Measurements of Cytokines in Serum}

The peripheral blood samples were obtained on day 7 after transplantation and clotted for $5 \mathrm{~h}$ at room temperature before centrifugation for 15 minutes at $2000 \mathrm{~g}$. The serums were collected and stored at $-80^{\circ} \mathrm{C}$. The serum concentrations of IFN- $\gamma$, TNF- $\alpha$ and IL- 6 were quantitated using a mouse Th cytometric bead array kit (BD Biosciences, NJ, US) (Biolegend, Cal., US) according to the manufacturer's instructions.

\section{Real-Time Quantitative PCR (qPCR)}

qPCR was performed for quantitative analyses in an ABI Prism 7000 Sequence Detection System (Applied Biosystems). Amplifications were performed using Power SYBR ${ }^{T M}$ Green PCR Master Mix (Thermo Fisher Scientific, MA, US). The quantification data were analyzed with ABI Prism 7000 SDS software. The expression levels of the target genes were normalized to the internal standard gene GAPDH using the comparative Ct method (ddCt). Primers used in qPCR to examine the genes:

Foxp3:

Forward Primer (5'-3') TTTCACCTATGCCACCCTTATC Reverse primer (5'-3') CATGCGAGTAAACCAATGGTAG CCL5

Forward Primer (5'-3') GTATTTCTACACCAGCAGCAAG Reverse primer (5'-3') TCTTGAACCCACTTCTTCTCTG CXCL9

Forward Primer (5'-3') AATCCCTCAAAGACCTCAAACA Reverse primer (5'-3') TCCCATTCTTTCATCAGCTTCT CXCL10

Forward Primer (5'-3') CAACTGCATCCATATCGATGAC Reverse primer (5'-3') GATTCCGGATTCAGACATCTCT GAPDH

Forward Primer (5'-3') CACCAACTGCTTAGCCCCC Reverse primer (5'-3') TCTTCTGGGTGGCAGTGATG

\section{Statistical Analysis}

Survival curve was analyzed using Kaplan-Meier method. Differences between groups in survival studies were determined using log-rank test. A student $t$ test was applied for the other studies. Independent experiment was performed 3 times. The results in the repeats were similar in this study. $\mathrm{p}<0.05$ is considered statistically significant. ${ }^{*} \mathrm{p}<0.05,{ }^{* *} \mathrm{p}<0.01$, and ${ }^{* * *} \mathrm{p}<0.001$. Analyses were performed using GraphPad Prism 7.

\section{RESULTS}

\section{LYG1 Deficiency Inhibited Alloreactivity of CD4 $^{+}$T Cells In Vitro}

Firstly, we examined whether LYG1 affected the alloreactivity of $\mathrm{CD} 4^{+} \mathrm{T}$ cells in vitro by MLR assay. The expression of the activation maker CD69 on CD4 ${ }^{+} \mathrm{T}$ cells were decreased in $\mathrm{Lyg1^{-1 }}$ mice compared with the $L y g 1^{+/+}$mice (Figure 1A), so was for the IFN- $\gamma$ production (Figure 1B). While the percentages of Treg cells gated on $\mathrm{CD}^{+} \mathrm{T}$ cells were higher in $\mathrm{Lyg1} \mathrm{1}^{-/}$group than Lyg $1^{+/+}$group (Figure 1C). The control group (without stimulating cells) had not response (Figure 1S). Whereas there were no differences in the expression of CD69, IFN- $\gamma$ and Foxp3 between $\operatorname{Lyg1^{+/+}}$ and $L y g 1^{-/-}$mice prior to the culture (Figure 1D). These results suggest that LYG1 deficiency restrains the alloreactivity of $\mathrm{CD} 4^{+} \mathrm{T}$ cells in vitro.

\section{LYG1 Deficiency in Donor T Cells Alleviated aGVHD}

We adopted a major MHC mismatched aGVHD model to examine the role of LYG1 in the development of aGVHD (Figure 2A). There were no differences in distribution of 


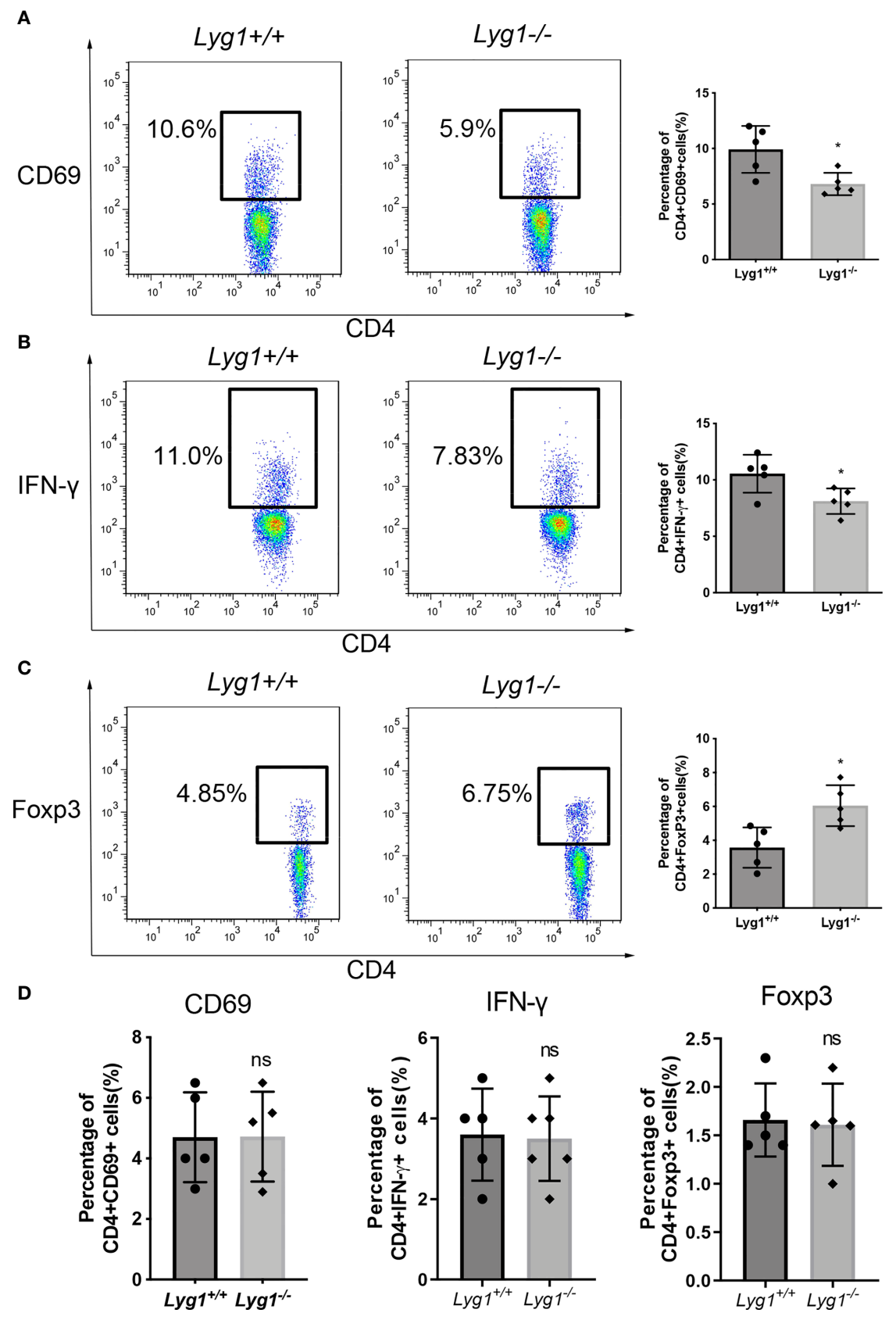

FIGURE 1 | LYG1 deficiency inhibited alloreactivity of CD4 ${ }^{+} \mathrm{T}$ cells in vitro. In MLR assay, CD3 ${ }^{+} \mathrm{T}$ cells from $L y g 1^{+/+}$or $L y g 1^{-/-}$mice as responder cells were cultured with mitomycin treated splenocytes from BALB/c mice as stimulator cells. After 5 days, CD69 expression (A), Th1 (B) and Treg (C) in the responder CD4 ${ }^{+} \mathrm{T}$ cells were detected by flow cytometry analysis. (D) The expression of CD69, IFN- $\gamma$ and Foxp3 gated on $L y g 1^{+/+}$and $L y g 1^{-/-}$CD $4^{+} \mathrm{T}$ cells prior to the culture. Independent experiment was performed 3 times. $n=5$ per group. Representative plots gated on $\mathrm{H} 2 \mathrm{~Kb}+\mathrm{CD} 4+\mathrm{T}$ cells are shown and statistical results are expressed as the mean $\pm \mathrm{SD},{ }^{*} \mathrm{p}<0.05$ compared with $\angle y g 1^{+/+}$group. ns, no significance.

$\mathrm{T}$ cells subsets, including naive (the most dominant subset), central memory and effector $\mathrm{CD} 4^{+} \mathrm{T}$ cells and $\mathrm{CD} 8^{+} \mathrm{T}$ cells, from $\operatorname{Lyg}_{1}{ }^{+/+}$and $\operatorname{Lyg} 1^{-/-}$mice before adoptive transfer (Figure S2). As shown in Figures 2B, C, the control mice in BM group (only transplantation of BM) and Syn group did not induce aGVHD. Comparing with recipients receiving Lyg $1^{+/+} \mathrm{T}$ cells, recipients receiving $\operatorname{Lyg} 1^{-/-} \mathrm{T}$ cells showed significantly higher long-term survival rates (Figure 2B), less weight loss (Figure 2C), 
A

C57BL/6 H2Kb

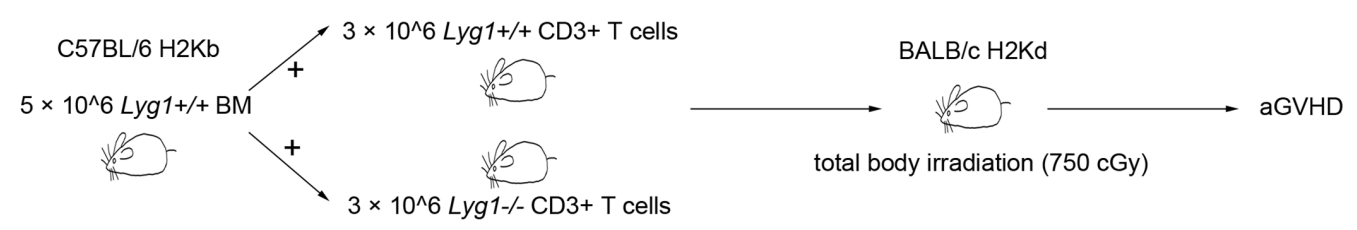

B

$$
\bullet \operatorname{Lyg} 1^{+/+} \simeq \mathrm{BM}
$$$$
-\bullet \operatorname{Lyg} 1^{-1-} \quad \text {... Syn }
$$

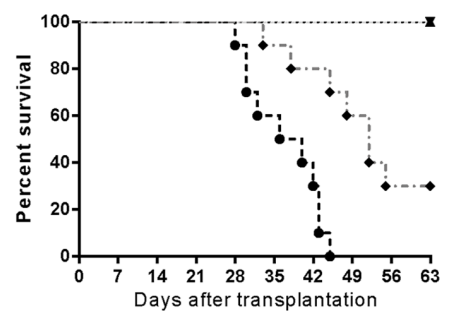

E

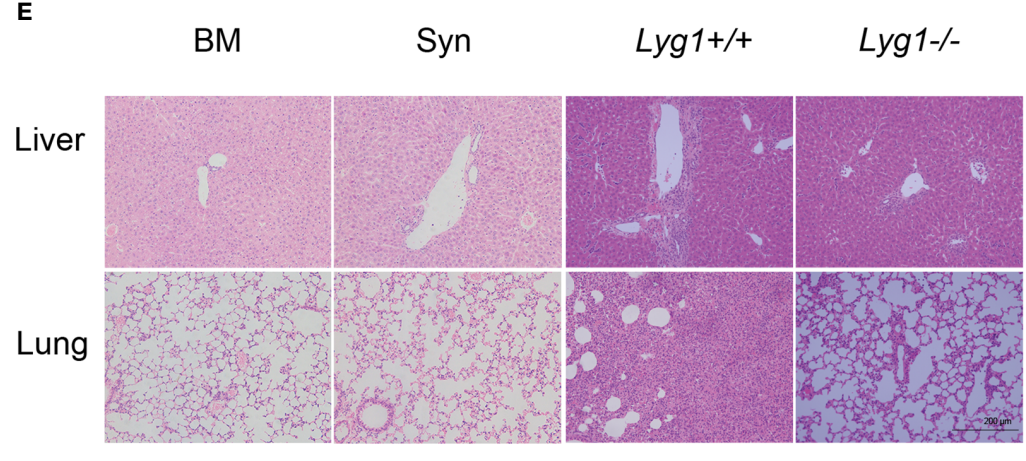

D

C

- $\operatorname{Lyg} 1^{+/+} \perp \mathrm{BM}$

$\bullet \quad \operatorname{Lyg}^{-} \quad \rightarrow$ Syn

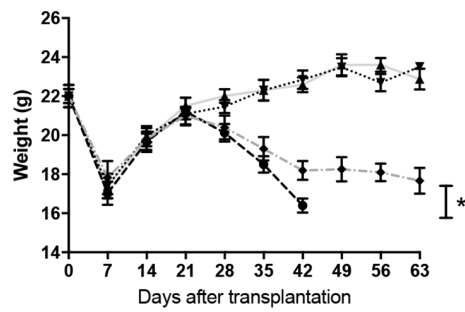

Days after transplantation

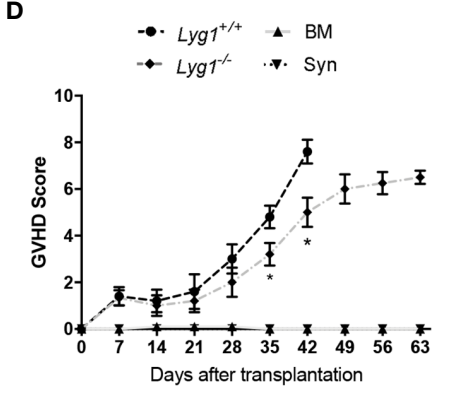

$\mathbf{F}$

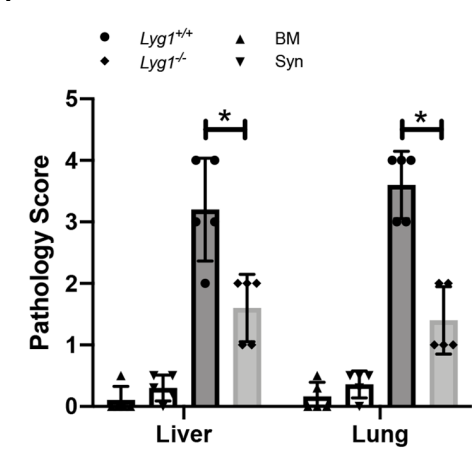

G

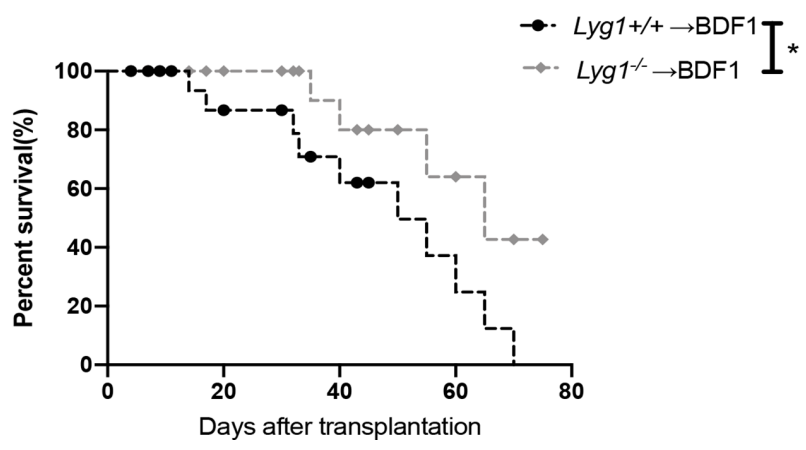

FIGURE 2 | LYG1 deficiency in donor T cells alleviated aGVHD. Lethally irradiated BALB/c mice were reconstituted with $5 \times 10^{6}$ Lyg $1^{+/+}$BM and $3 \times 10^{6} \mathrm{~T}$ cells from $L y g 1^{+/+}$mice $\left(L y g 1^{+/+}\right.$group) or $L y g 1^{-/-}$mice $\left(L y g 1^{-/-}\right.$group). BM control (BM group) were given $5 \times 10^{6} \mathrm{Lyg} 1^{+/+} \mathrm{BM}$ alone. (A) The diagram illustrating the experimental procedure. Survival (B), weight (C) and aGVHD scores (D) were monitored. (E) Histological examination ( $\times 200$ magnification) of liver and lung in four groups were analyzed on day 28 after transplantation. (F) Histologic scores of liver and lung were shown. (G) Survival of BDF1 recipients given transplants with $5 \times$ $10^{6} \mathrm{Lyg} 1^{+/+} \mathrm{BM}$ and $2 \times 10^{7}$ splenocytes from $\operatorname{Lyg} 1^{+/+}$mice $\left(L y g 1^{+/+}\right.$group) or $L y g 1^{-/-}$mice ( $L y g 1^{-/-}$group). Independent experiment was performed 3 times. Data pooled: 3 experiments $\left(n=10\right.$ for $L y g 1^{+/+}$group and $L y g 1^{-/}$group, $n=5$ for BM group). Results are expressed as the mean $\pm S D$, ${ }^{*} p<0.05$ compared with $L y g 1^{+/+}$group.

and lower aGVHD clinical scores (Figure 2D) after 3 weeks since the allogeneic transplantation. Pathology revealed that mice receiving Lygl $^{-1-} \mathrm{T}$ cells showed dramatically reduced inflammation in the livers and lungs compared with those receiving Lyg $^{+/+} \mathrm{T}$ cells (Figure $2 \mathrm{E}$ ). The histological grades of livers and lungs were significantly decreased in recipients receiving $\mathrm{Lygl}^{-/-}$donor $\mathrm{T}$ cells (Figure $2 \mathbf{F}$ ). There was no pathological lesion and inflammation in BM group and Syn 
group (Figures 2E, F). We also examined the LYG1 effect on aGVHD using haplo-HSCT model. The mice receiving Lyg1 ${ }^{-1-} \mathrm{T}$ cells also exhibited a higher survival rate than did the control mice (Figure 2G). These results proved that LYG1 deficiency in donor $\mathrm{T}$ cells decreased aGVHD mortality and severity.

\section{LYG1 Deficiency in Donor T Cells Dampened the Function of Allogeneic $\mathrm{CD}^{+} \mathrm{T}$ Cells in Spleens}

First, we examined the donor chimerism in the spleen of recipient mice on day 7 after transplantation. Nearly $98 \%$ of $\mathrm{H} 2 \mathrm{~Kb}+$ donor cells can be observed in recipient spleens in $L y g 1^{+/+}$and $L y g 1^{-/-}$ aGVHD groups (Figure 3A), suggesting LYG1 deficiency in donor $\mathrm{T}$ cells did not affect the engraftment of donor cells. To explore potential regulation mechanisms for LYG1 in aGVHD, we investigated the activation and differentiation of $\mathrm{H} 2 \mathrm{~Kb}+$ donor $\mathrm{T}$ cells from recipients receiving either $L y g 1^{+/+}$or $L y g 1^{-/-} \mathrm{T}$ cells. We did not observe notable difference in the absolute number (data not shown) and ratio of $\mathrm{CD}^{+}$or $\mathrm{CD} 8^{+} \mathrm{T}$ cells between the two groups (Figure 3B); however, we noticed significant decrease of CD69 expression on $\mathrm{CD}^{+} \mathrm{T}$ in mice receiving $L y g 1^{-/-} \mathrm{T}$ cells (Figures $3 \mathrm{C}$, D), suggesting reduced activation of $\mathrm{CD}^{+}{ }^{+} \mathrm{T}$ cells in these mice. The effector $\mathrm{T}$ cells $\left(\mathrm{CD} 44^{\mathrm{hi}} \mathrm{CD} 62 \mathrm{~L}^{\text {lo }}\right.$ ) also decreased in mice receiving Lyg1 $1^{-/-} \mathrm{T}$ cells (Figures 3E, F). The IFN- $\gamma$ producing $\mathrm{CD}^{+}$(Th1) and IFN- $\gamma$ producing $\mathrm{CD}^{+} \mathrm{T}$ cells (Tc1, T cytotoxic 1) were significantly reduced in recipients of $L y g 1^{-/-} \mathrm{T}$ cells compared with those of $L y g 1^{+/+}$group (Figures 3G, H). T-bet is a master regulator for Th1 differentiation and IFN- $\gamma$ production (18). Then we examined T-bet and found the percentages of T-bet on $\mathrm{CD}^{+}{ }^{+} \mathrm{T}$ cells were lower in mice receiving Lyg1 ${ }^{-1-} \mathrm{T}$ cells (Figure 3I).

Treg cells have been shown to be capable of reducing the severity of aGVHD by restraining immoderate immune activation and maintaining immune homeostasis (19). We found that the proportions of Treg cells (Foxp3+ gated on $\mathrm{CD}^{+} \mathrm{T}$ cells) in spleens were dramatically enhanced from recipients received Lyg1 $^{-/}$donor T cells (Figure 3J), suggesting LYG1 deficiency in donor $\mathrm{T}$ cells promotes Treg differentiation. Interestingly, the proportions of Foxp3+ population gated on $\mathrm{CD}^{+} \mathrm{T}$ cells increased in spleens in $L y g 1^{-/-}$group than $\mathrm{Lygl}^{+/+}$group (Figure 3K). The mRNA expression of Foxp3 in spleens were also higher in recipients received $L y g 1^{-/-}$donor T cells (Figure 3L).

We found the similar results in the haplo-HSCT model, LYG1 deficiency in donor T cells decreased the expression of CD69 and IFN- $\gamma$, but increased the expression of FoxP 3 on $\mathrm{T}$ cells (Figure S3). Whereas the BM and Syn control group had a lower T cells response (Figure S4).

\section{LYG1 Deficiency in Donor T Cells Inhibited Allogeneic CD4 ${ }^{+} \mathrm{T}$ Cells Infiltration in aGVHD Target Organs}

We also evaluated the lymphocytes in livers and lungs, the representative target organs of aGVHD. Similarly with spleens, the infiltrating lymphocytes were almost $\mathrm{H} 2 \mathrm{~kb}+$ donor cells (data not shown). A significant reduction of $\mathrm{CD}^{+} \mathrm{T}$ cells in livers and lungs were observed in mice receiving $L y g 1^{-/-}$ donor $\mathrm{T}$ cells compared with the $L y g 1^{+/+}$group determined by
IHC (Figure 4A). $\mathrm{CD}^{+} \mathrm{T}$ cells infiltration in aGVHD target organs also reduced slightly in $\mathrm{Lygl}^{-/-}$group (Figure 4B). The $\mathrm{T}$ cells infiltration in livers and lungs were rarely detected in BM and Syn control group. The decrease of T cells infiltrating in livers and lungs suggested that LYG1 deficiency might change the expression of chemokines that recruited $\mathrm{T}$ cells. Therefore, we examined the expression of CCL5, CXCL9, CXCL10 in livers and lungs. LYG1 deficiency inhibited significantly the mRNA expression of CXCL9 and CXCL10, but had no obvious effect on CCL5 expression (Figures 4C, D).

\section{LYG1 Deficiency in Donor T Cells Inhibited the Function of Allogeneic CD4 ${ }^{+} \mathrm{T}$ Cells in GVHD Target Organs}

LYG1 deficiency reduced the number of $\mathrm{T}$ cells infiltrating in GVHD target organs, whether it affect allogeneic T cells function? Therefore, we investigated the activation and differentiation of donor $\mathrm{T}$ cells in livers and lungs from recipients receiving either Lyg1 $1^{+/+}$or $L y g 1^{-/-}$T cells. Similarly, the CD69 and IFN- $\gamma$ expression of $\mathrm{CD}^{+} \mathrm{T}$ cells and $\mathrm{CD} 8^{+} \mathrm{T}$ cells decreased in $\mathrm{Lyg1^{-/ }}$ recipient livers and lungs compared with the $L y g 1^{+/+}$groups (Figures 5A-D). The percentages of Foxp3+ population gated on $\mathrm{CD} 4^{+} \mathrm{T}$ cells and $\mathrm{CD} 8^{+}$ $\mathrm{T}$ cells were higher in livers and lungs in $\mathrm{Lyg1^{-/ }}$ group than $\mathrm{Lyg1^{+/+ }}$ group (Figures 5E, F). The expression of Foxp3 in mRNA level in livers and lungs also increased in recipients received $\operatorname{Lyg} 1^{-/-}$donor $\mathrm{T}$ cells (Figures 5G, H).

\section{LYG1 Mediated GVHD Development Mainly Through CD4 ${ }^{+}$T Cells}

To test whether the effects of LYG1 on GVHD mediated through $\mathrm{CD}^{+} \mathrm{T}$ cells or $\mathrm{CD}^{+} \mathrm{T}$ cells, we performed GVHD models using purified $\mathrm{CD}^{+} \mathrm{T}$ cells or $\mathrm{CD}^{+} \mathrm{T}$ cells as grafts, respectively. As illustrated in Figures 6A, F, the reduction of aGVHD lethality by LYG1 deficiency was observed in $\mathrm{CD} 4^{+} \mathrm{T}$ cells transplant, but not $\mathrm{CD} 8^{+} \mathrm{T}$ cells transplant. LYG1 deficiency in CD4+ T cells transplant significantly reduced the activation of $\mathrm{CD} 4^{+} \mathrm{T}$ cells and IFN- $\gamma$ and T-bet expression, but increased Treg ratio (Figures 6B-E), but not in $\mathrm{CD}^{+} \mathrm{T}$ cells transplant (Figures 6G-I). Taken together, the results suggested that LYG1-mediated GVHD development mainly depended on $\mathrm{CD}^{+} \mathrm{T}$ cells, but not $\mathrm{CD}^{+} \mathrm{T}$ cells.

\section{rhLYG1 Aggravated aGVHD via Promoting IFN- $\gamma$ Production and Inhibiting Foxp3 Expression}

Furthermore, we used the purified rhLYG1 to evaluate the role of LYG1 in aGVHD model. As shown in Figures 7A, B, rhLYG1 significantly accelerated and exacerbated the death and weight loss compared with PBS control. Higher clinical aGVHD scores were seen in rhLYG1 group than in control group (Figure 7C). The IFN- $\gamma$ production of $\mathrm{CD}^{+} \mathrm{T}$ cells and $\mathrm{CD}^{+} \mathrm{T}$ cells (Th1 and Tc1 cells) were significantly higher than PBS control in spleens (Figures 7D, E). The mRNA expression of FoxP3 in spleens decreased in mice treated with rhLYG1 compared with PBS (Figure 7F). The IFN- $\gamma$ concentrations in serum from mice treated with rhLYG1 were higher than that from 

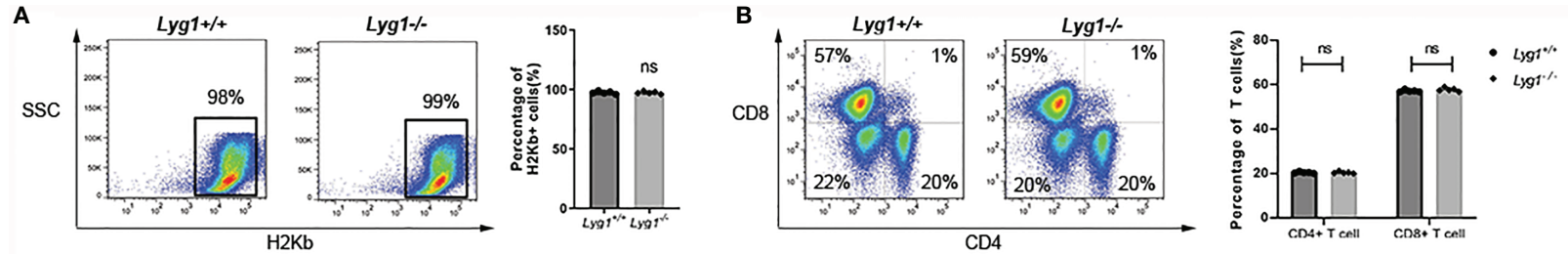

C
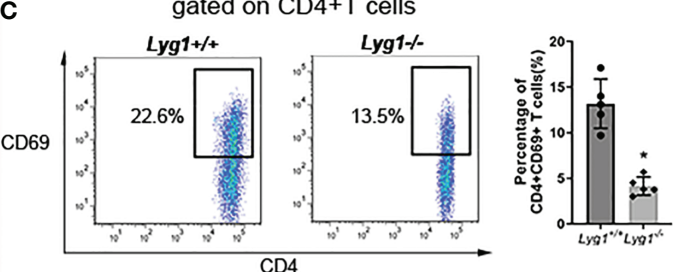

E
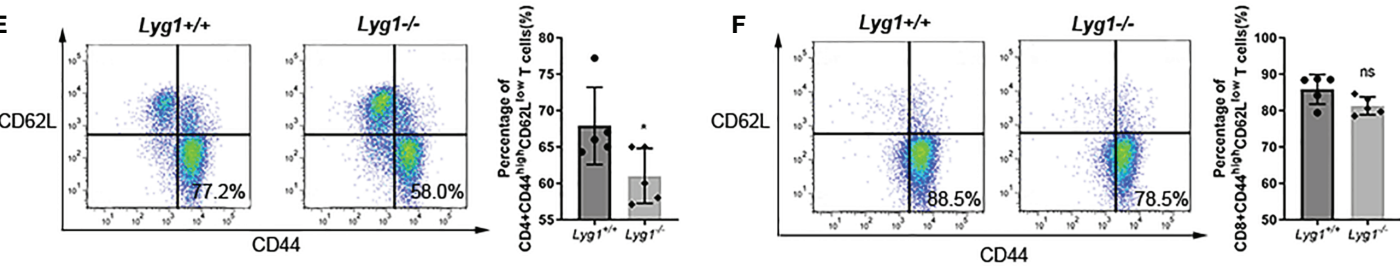

G
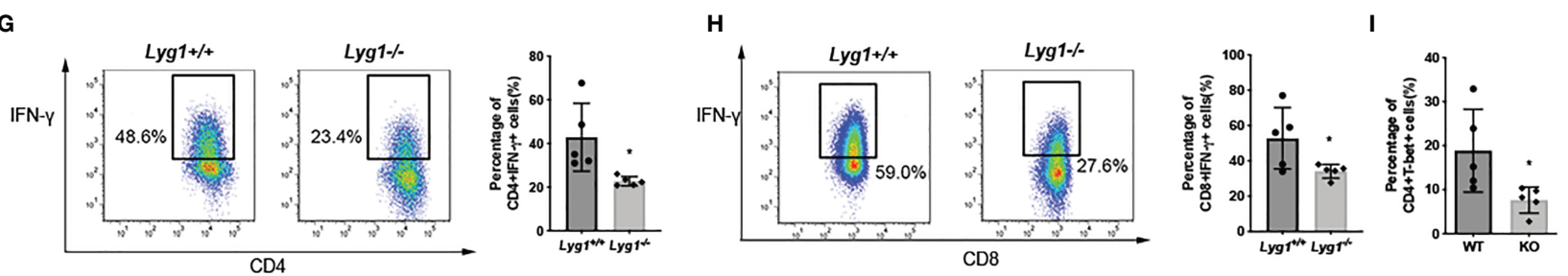

$\mathbf{J}$
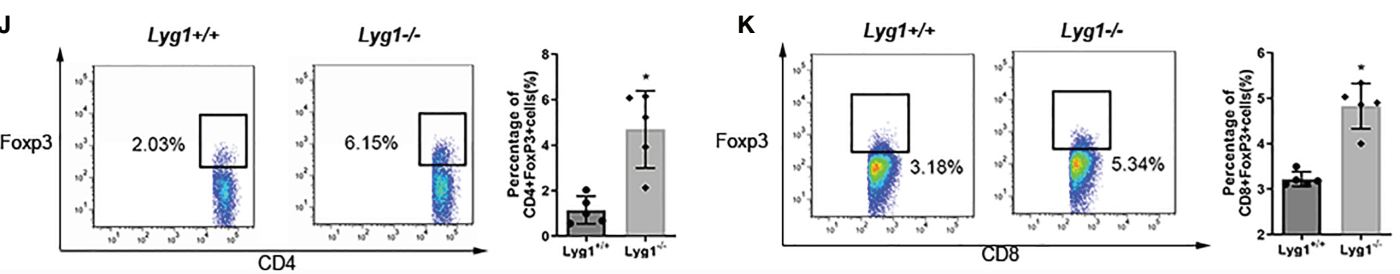

$\mathbf{L}$

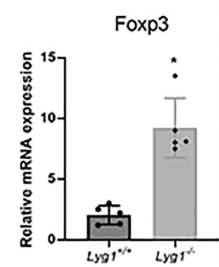

FIGURE 3 | LYG1 deficiency reduced allogeneic T cells function in spleens. Splenocytes of recipient mice were isolated on day 7 after transplantation and analyzed by flow cytometry and qPCR. (A) The percentages of $\mathrm{H} 2 \mathrm{~Kb}+$ cells in living splenocytes. (B) The percentages of CD4 ${ }^{+} \mathrm{T}$ and $\mathrm{CD} 8^{+} \mathrm{T}$ cells in $\mathrm{H} 2 \mathrm{~Kb}+$ splenocytes. (C, D) The percentages of CD69 expression in CD4 ${ }^{+} \mathrm{T}$ cells and CD8 ${ }^{+} \mathrm{T}$ cells. (E, F) The expression of effector $\left(\mathrm{CD} 44^{\text {hi }} \mathrm{CD} 62 \mathrm{~L}^{\mathrm{lo}}\right)$ phenotype gated on $\mathrm{CD} 4^{+} \mathrm{T}$ and

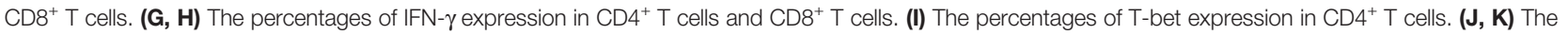
percentages of Treg in $\mathrm{CD}^{+} \mathrm{T}$ cells and $\mathrm{CD}^{+} \mathrm{T}$ cells. The percentages of Figure $\mathbf{3}$ (C-K) were all gated on $\mathrm{H}_{2} \mathrm{~Kb}^{+} \mathrm{CD} 4^{+}$cells or $\mathrm{H} 2 \mathrm{~Kb}^{+} \mathrm{CD} 8^{+}$cells. (L) Foxp3 expression of splenocytes were examined by qPCR. Independent experiment was performed 3 times. The results in the repeats were similar. $\mathrm{n}=5$ per group. Representative plots are shown and statistical results are expressed as the mean $\pm \mathrm{SD},{ }^{*} \mathrm{p}<0.05$ compared with $L y g 1^{+/+}$group. ns, no significance.

PBS group (Figure 7G). We also detected the IFN- $\gamma$, TNF- $\alpha$ and IL- 6 in serum in the above GVHD models and found that the concentrations of IFN- $\gamma$, TNF- $\alpha$ and IL- 6 reduced in recipients received $L y g 1^{-/-}$donor $\mathrm{T}$ cells compared with recipients received $L y g 1^{-/-}$donor T cells, especially for IFN- $\gamma$ (Figure S5). Further we verified the role of IFN- $\gamma$ in the effects of LYG1 on GVHD using IFN- $\gamma^{-1} \mathrm{~T}$ cells as grafts. As showed in Figures $7 \mathbf{H}-\mathbf{J}$, with the deficiency of IFN- $\gamma$, the effect of rhLYG1 aggravating aGVHD was partially abrogated, which reconfirmed the crucial role of IFN- $\gamma$ in LYG1-mediated GVHD development.

\section{LYG1 Deficiency in Donor T Cells Preserved GVT Response}

To determine whether the reduction of aGVHD lethality by LYG1 deficiency would affect GVT activity, mouse mastocytoma cell strain P815 (H2Kd) were injected intravenously on day 0 to 
A CD4+ T cells
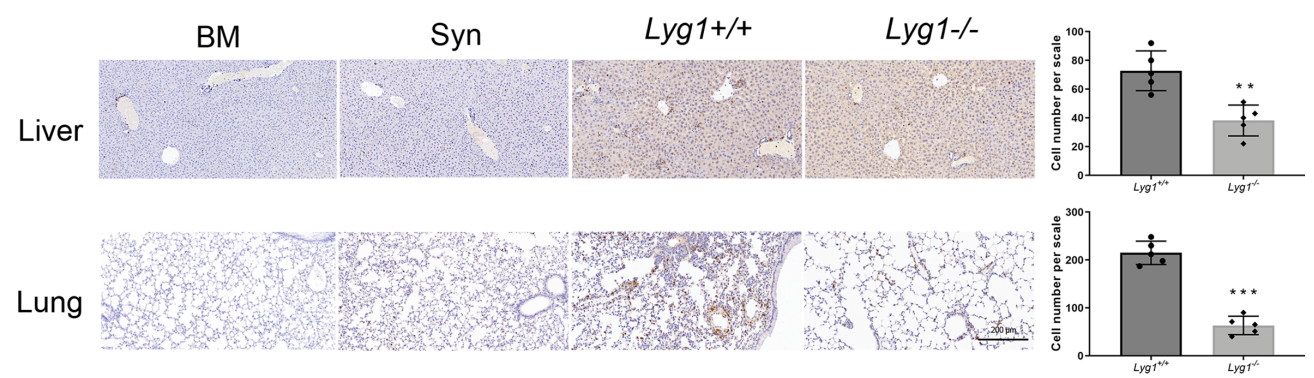

B $\mathrm{CD} 8+\mathrm{T}$ cells

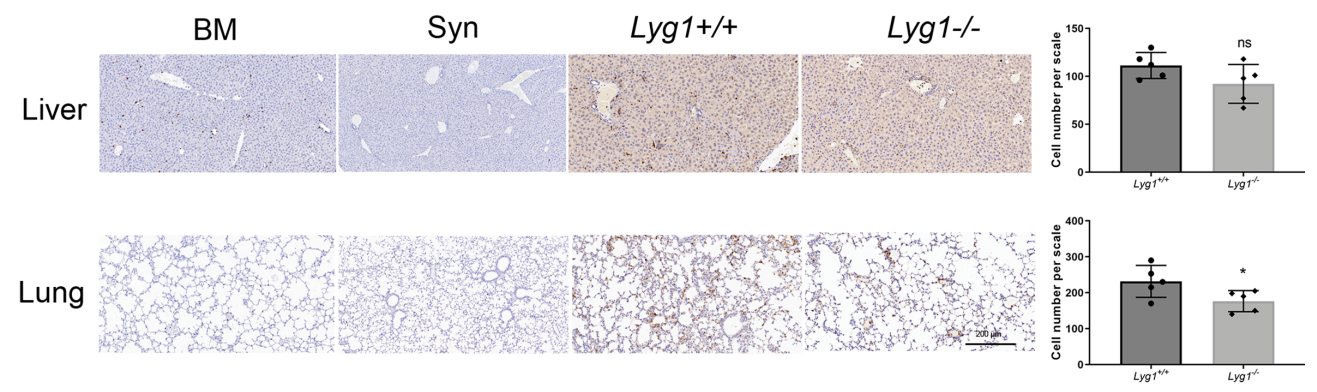

C

CXCL9

CXCL10

CCL5

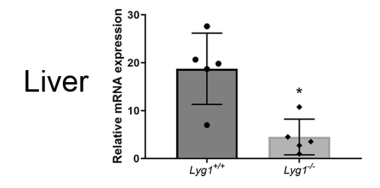

D
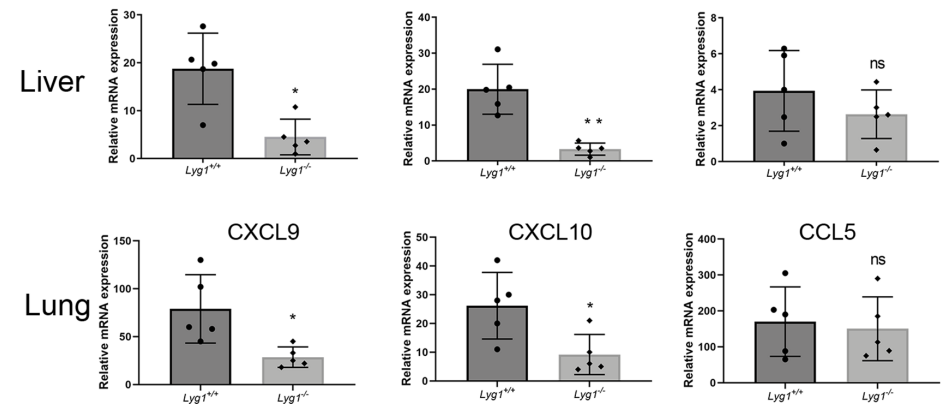

FIGURE 4 | LYG1 deficiency inhibited allogeneic CD4 ${ }^{+}$T cells infiltration in aGVHD target organs. The samples of livers and lungs were excised at day 7 after transplantation and stained with antibodies CD4 and CD8. (A, B) The infiltration of $C D 4^{+} T$ cells and $C D 8^{+} T$ cells in livers and lungs in BM, Syn group, or mice receiving $L y g 1^{+/+}$and $L y g 1^{1 /-}$ donor T cells determined by IHC assay (×200 magnification). The left is one representative section per group. The right is the number of $\mathrm{CD}^{+} \mathrm{T}$ cells and $\mathrm{CD} 8^{+} \mathrm{T}$ cells per scale in the livers and lungs. (C, D) Chemokines expression were examined by qPCR in lymphocytes isolated from livers and lungs. Independent experiment was performed 3 times. The results in the repeats were similar. $n=5$ per group. Representative sections are shown and statistical results are expressed as the mean $\pm \mathrm{SD},{ }^{\star} \mathrm{P}<0.05,{ }^{* *} \mathrm{P}<0.01$ and ${ }^{* \star *} \mathrm{P}<0.001$ compared with $\mathrm{Lyg} 1^{+/+}$group. ns, no significance.

generate murine GVT model. The mice receiving $L y g 1^{-/-} \mathrm{T}$ cells exhibited a higher survival rate, lower tumor signal and lower tumor burden than that of the mice receiving Lyg1 $1^{+/+} \mathrm{T}$ cells and $\mathrm{BM}$ cells (Figures 8A-C). Furthermore, there was no evident GVHD as the time of death in GVT model mice. The results suggested that targeting LYG1 might be an alternative to ameliorating aGVHD without impairing GVT function.

\section{DISCUSSION}

In this study, the role and mechanisms of LYG1 in aGVHD were explored. We demonstrated that mice receiving $L y g 1^{-/-}$donor $\mathrm{T}$ cells alleviated aGVHD, increased long-term survival rates, showed less weight loss, lower GVHD clinical pathological scores and milder tissues damages, than mice receiving $L y g 1^{+/+}$ donor T cells in $\mathrm{CD}^{+}$or $\mathrm{CD}^{+}$T cells transplanting-major $\mathrm{MHC}$ mismatched aGVHD model and in haplo-HSCT model. Additionally, rhLYG1 intraperitoneally administration aggravated aGVHD severity, which confirmed the results established in the $\operatorname{Lyg} 1^{-/-}$mice. Furthermore, we discovered that LYG1 deficiency in donor T cells can decrease infiltration of alloreactive $\mathrm{CD}^{+} \mathrm{T}$ cells in aGVHD mice target organs, inhibit alloreactive of $\mathrm{CD}^{+} \mathrm{T}$ cells and Th1 differentiation, promote Treg differentiation of allogeneic $\mathrm{CD}^{+} \mathrm{T}$ cells in vitro and in vivo.

Donor-derived $\mathrm{CD} 4^{+} \mathrm{T}$ cells are particularly important in the pathogenesis of aGVHD. A large number of clinical trials have 


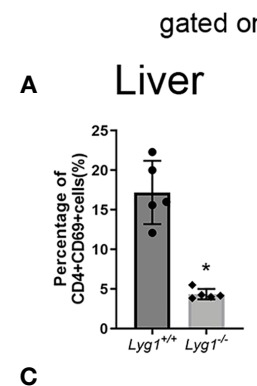

C

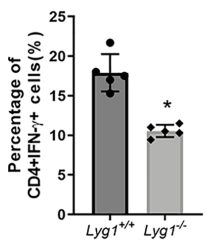

E

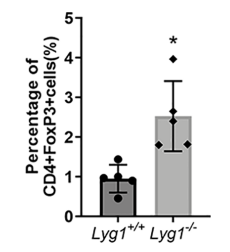

G

Liver

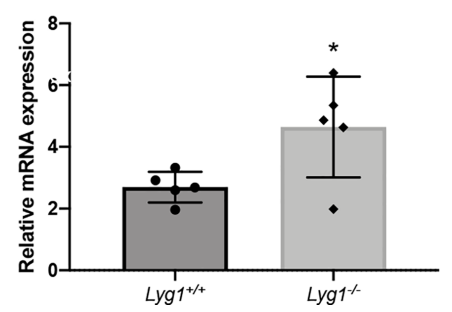

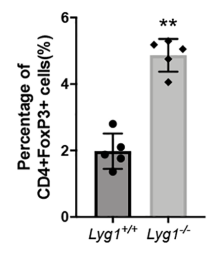

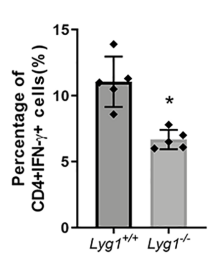

Lung

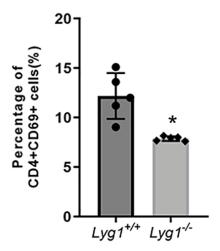

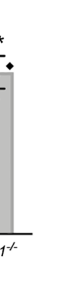

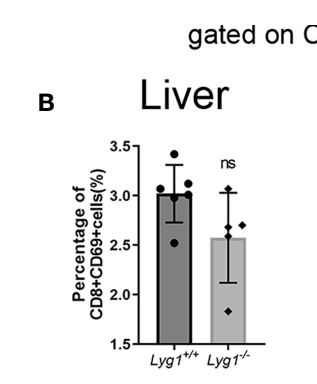

D

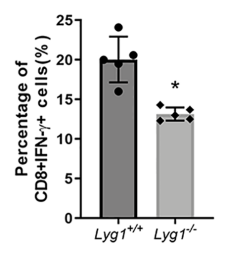

F
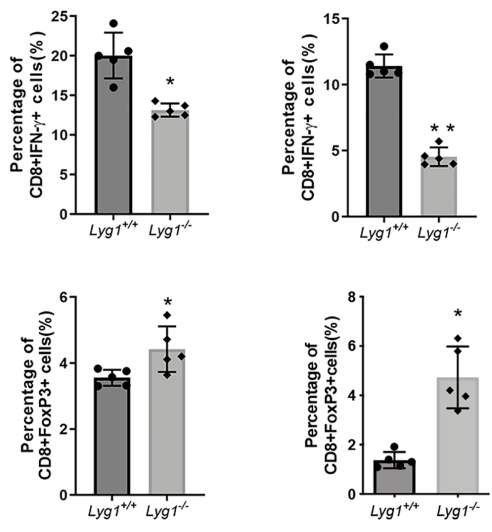

H

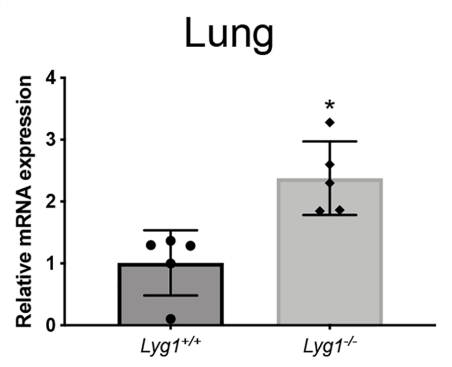

FIGURE 5 | LYG1 deficiency inhibited allogeneic T cells function in livers and lungs. Lymphocytes were isolated from livers and lungs of recipient mice on day 7 after transplantation and analyzed by flow cytometry and qPCR. (A, B) The percentages of CD69 expression in CD4 ${ }^{+} \mathrm{T}$ cells and CD8 ${ }^{+} \mathrm{T}$ cells. (C, D) The percentages of IFN- $\gamma$ expression in $\mathrm{CD}^{+} \mathrm{T}$ cells and CD8 ${ }^{+} \mathrm{T}$ cells. (E, F) The percentages of Treg in CD4 ${ }^{+} \mathrm{T}$ cells and CD8 ${ }^{+} \mathrm{T}$ cells. The percentages of $\mathbf{F i g u r e} \mathbf{5}(\mathbf{A}-\mathbf{F})$ were all gated on $\mathrm{H} 2 \mathrm{~Kb}+\mathrm{CD} 4+$ cells or $\mathrm{H} 2 \mathrm{~Kb}+\mathrm{CD} 8+$ cells in lymphocytes isolated from livers and lungs. (G, $\mathbf{H})$ Foxp3 expression of lymphocytes isolated from livers and lungs were examined by qPCR. Independent experiment was performed 3 times. The results in the repeats were similar. $n=5$ per group. Statistical results are expressed as the mean $\pm \mathrm{SD}$, ${ }^{*} \mathrm{p}<0.05$ and ${ }^{* \star} \mathrm{P}<0.01$ compared with $L y g 1^{+/+}$group. $\mathrm{ns}$, no significance.

taken $\mathrm{CD} 4^{+} \mathrm{T}$ cells as a potential target for GVHD treatment (3). Firstly we proved that LYG1 mediated GVHD development mainly through $\mathrm{CD}^{+} \mathrm{T}$ cells, but not $\mathrm{CD} 8^{+} \mathrm{T}$ cells by using purified $\mathrm{CD}^{+}$and $\mathrm{CD} 8^{+} \mathrm{T}$ cells as grafts. In aGVHD, alloreactive $\mathrm{CD} 4^{+} \mathrm{T}$ cells are directed by chemokines and migrate to target tissues and organs where they cause tissue injury (20-22). CXCL9, CXCL10-CXCR3 interactions has been linked to activated $\mathrm{T}$ cell trafficking to aGVHD target organs in humans and mice (16). Our previous study found that rhLYG1 administration in mice can enhance the expression of $\mathrm{T}$ cell chemokines, including CCL5, CXCL9 and CXCL10, and infiltration of $\mathrm{T}$ cells in tumors (11). In this study, the decreased infiltration of allogeneic $\mathrm{CD}^{+}{ }^{+} \mathrm{T}$ cells in the livers and lungs of mice that received $L y g 1^{-/-} \mathrm{T}$ cells, which maybe related that LYG1 deficiency inhibited the expression of CXCL9 and CXCL10, explained partially that LYG1 deficiency in donor T cells suppressed aGVHD.

Another mechanism for LYG1 deficiency alleviating GVHD was able to inhibit IFN- $\gamma$ production of donor derived T cells. IFN- $\gamma$ plays an important promoting role in the alloreactivity of donor derived T cells in aGVHD (23). However, other studies have found that IFN- $\gamma$ played a protective role against aGVHD, which depended on the time phase of IFN- $\gamma$ production in alloHSCT (23-25). Exogenous injection of IL-12 or IL-18 increased the expression of IFN- $\gamma$, thereby inducing the expression of Fas in donor $\mathrm{T}$ cells, leading to activation-induc,ed cell death, reducing donor $\mathrm{T}$ cells responses to host antigens and finally attenuating aGVHD $(26,27)$. Our previous studies have shown 
A

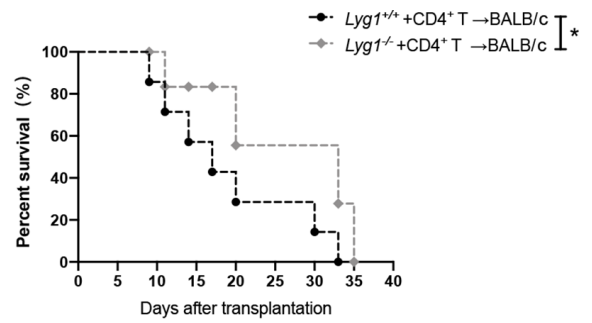

C
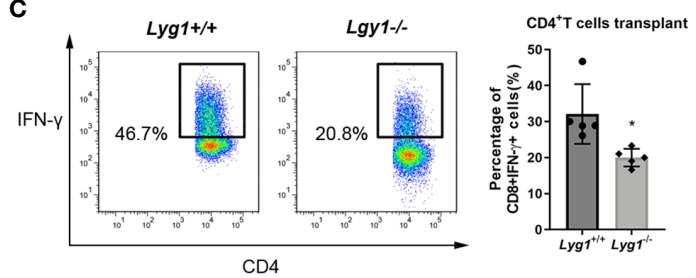

$\mathbf{F}$

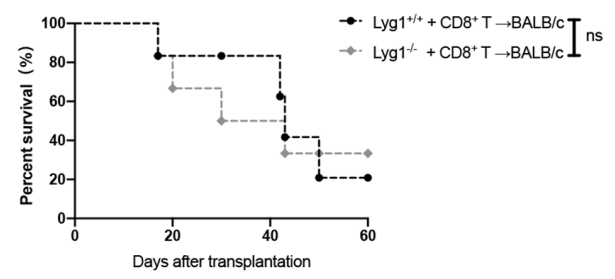

H
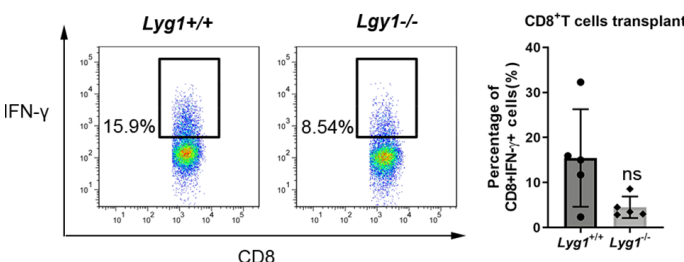

B
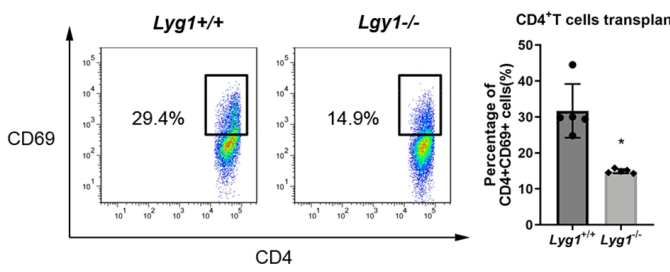

D
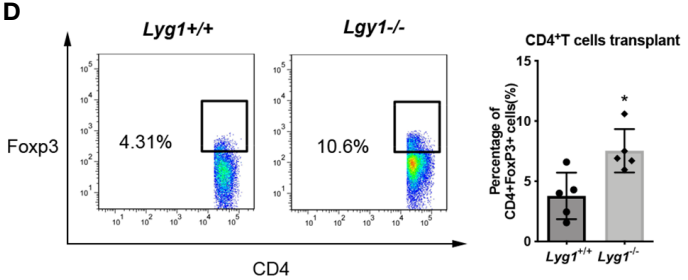

E

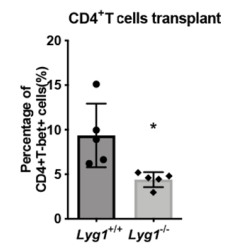

G
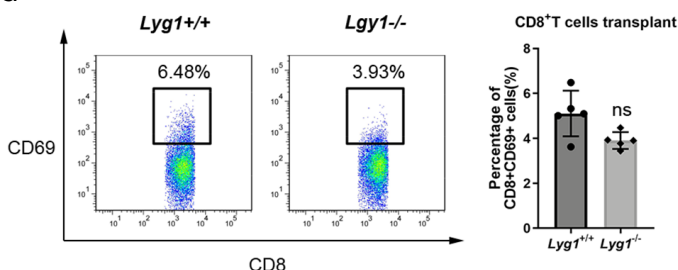

I

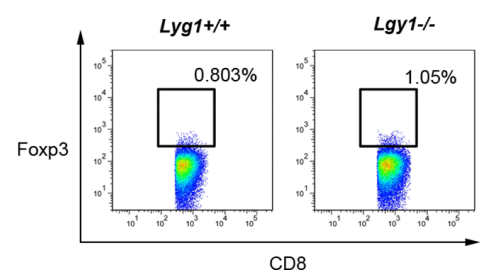

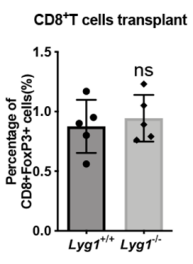

FIGURE 6 | LYG1 mediated aGVHD development mainly through CD4+ T cells. Survival of mice receiving CD4 ${ }^{+} \mathbf{( A )}$ and $\mathrm{CD}^{+}(\mathbf{F})$ donor T cells were monitored. Data pooled: $\mathrm{n}=10$ for $L y g 1^{+/+}$group and $L y g 1^{-/-}$group (A, F). (B-E) The expression of CD69, IFN- $\gamma$, Foxp3 and T-bet gated on CD4 ${ }^{+} T$ cells. (G-I) The expression of CD69, IFN- $\gamma$ and Foxp3 gated on CD8 ${ }^{+} T$ cells. $n=5$ per group (B-E, G-I). Representative plots are shown and statistical results are expressed as the mean \pm $\mathrm{SD},{ }^{*} \mathrm{p}<0.05$ compared with $L y g 1^{+/+}$group. ns, no significance.

that rhLYG1 can promote antigen specific activity and IFN- $\gamma$ production of T lymphocytes in tumor models (11). In this study, we found inhibited activation of $\mathrm{CD}^{+} \mathrm{T}$ cells and IFN- $\gamma$ expression of allogeneic $\mathrm{T}$ cells in mice receiving $L y g 1^{-1-}$ donor $\mathrm{T}$ cells, whereas rhLYG1 administration aggravated aGVHD severity through promoting IFN- $\gamma$ production of allogeneic $\mathrm{T}$ cells, more importantly, the absence of IFN- $\gamma$ in donor T cells could partially abrogate rhLYG1-induced GVHD development, corroborating that the effect of LYG1 on aGVHD were mainly mediated by IFN- $\gamma$.

Treg cells play a significant role in maintaining tolerance in aGVHD by limiting T cell function (28). Many studies have proven that therapeutic modulation or adoptive transfer of Treg can directly prevent GVHD (29). CD $8^{+} \mathrm{Foxp}^{+} \mathrm{T}$ cells, a Treg subpopulation, can be induced and ameliorate GVHD in mouse models (30). In our study, LYG1 deficiency led to the enhanced proportions of Treg cells in vitro. Similarly, the absence of LYG1 in donor $\mathrm{T}$ cells increased the proportions of allogeneic Treg $\left(\mathrm{CD}^{+}{ }^{+} \mathrm{Foxp}^{+} \mathrm{T}\right.$ cells and $\mathrm{CD}^{+} \mathrm{Foxp}^{+} \mathrm{T}$ cells) in different GVHD models in vivo. These results provided another explanation that LYG1 deficiency in donor $\mathrm{T}$ cells alleviated GVHD. Importantly, $\mathrm{CD}^{+} \mathrm{Foxp}^{+}$Treg cells display cytotoxic activity which can suppress tumor during GVHD (31). These results explained partially if not fully that LYG1 deficiency in donor T cells suppressing GVHD while preserving GVT effect.

Our study demonstrated that LYG1 deficiency in donor $\mathrm{T}$ cells suppressed Th1 cells and promoted Treg cells differentiation in aGVHD model. Th cell differentiation is regulated by multiple cytokines and transcription factors. In the absence of IL-6, TGF- $\beta$ stimulates a transcriptional program in naive $\mathrm{CD} 4^{+} \mathrm{T}$ cells with Foxp3 up-regulation and leads the evolvement of Treg cells (32).TNF- $\alpha$ blockade was shown to increase Foxp3 expression 


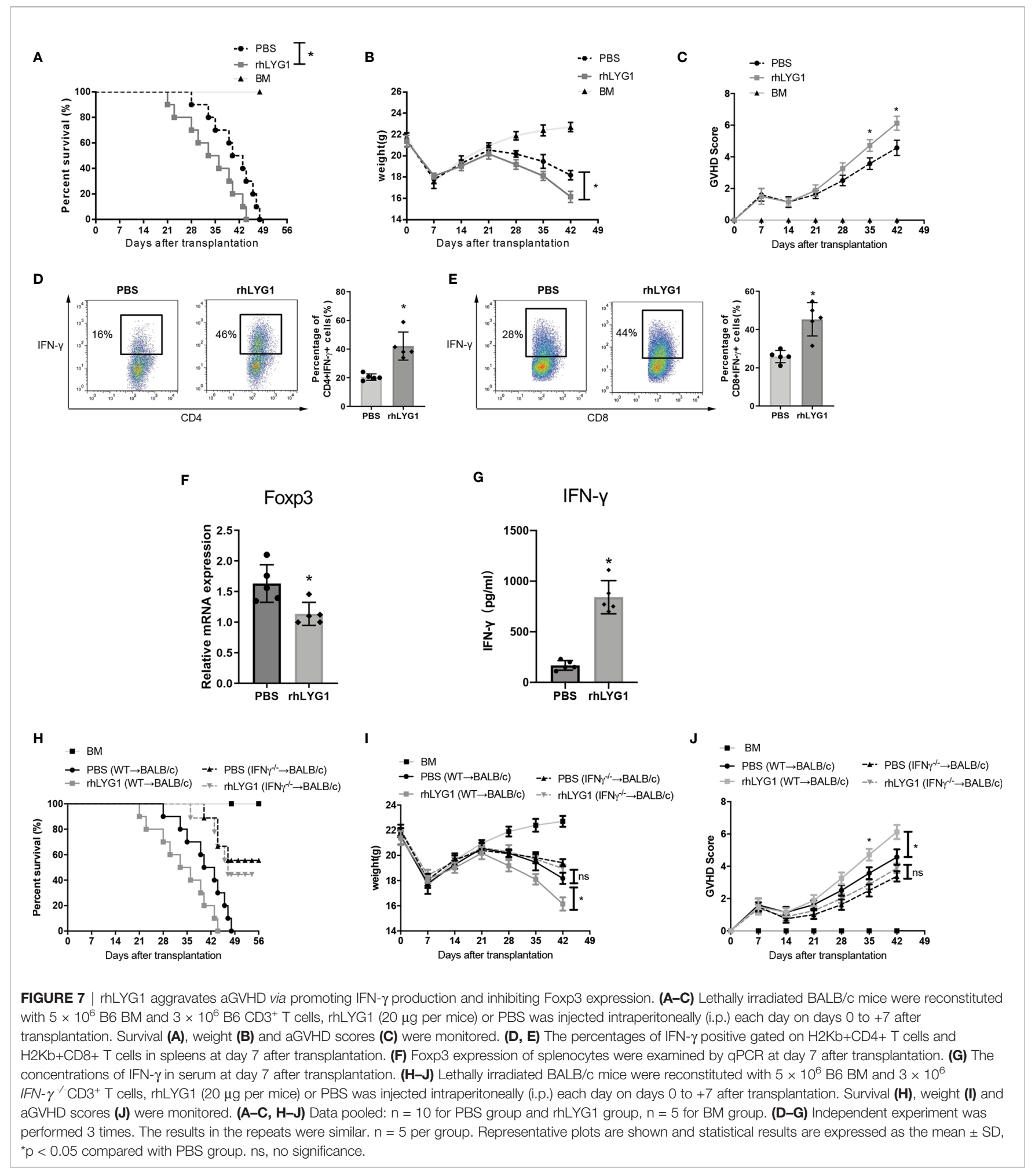

in patients with RA $(33,34)$. In this study, we found that the absence of LYG1 in donor T cells reduced the production of IL-6 and TNF- $\alpha$ in different GVHD models. Therefore, we speculated that LYG1 deficiency promoted Treg cells differentiation by inhibiting IL-6 and TNF- $\alpha$. T-bet is a transcriptional activator of IFN- $\gamma$ and orchestrates the cell-migratory program by directly controlling expression of the chemokine receptors CXCR3 (18). We showed that the absence of LYG1 decreased the expression of T-bet and CXCL10 in GVHD models. It was supposed that LYG1 deficiency suppressed Th1 cells polarization via inhibiting T-bet 
A

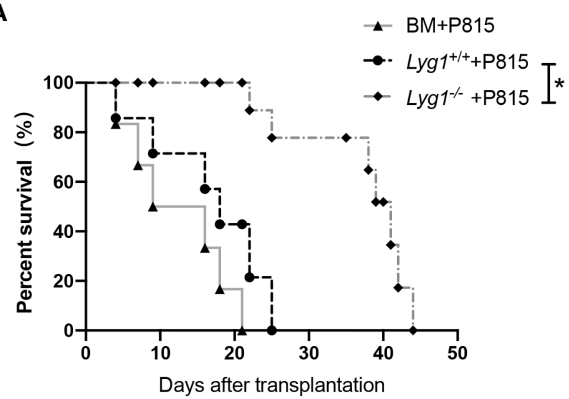

C

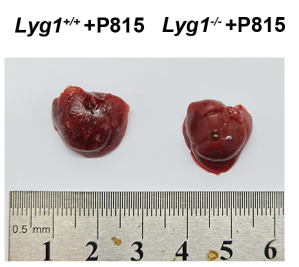

B
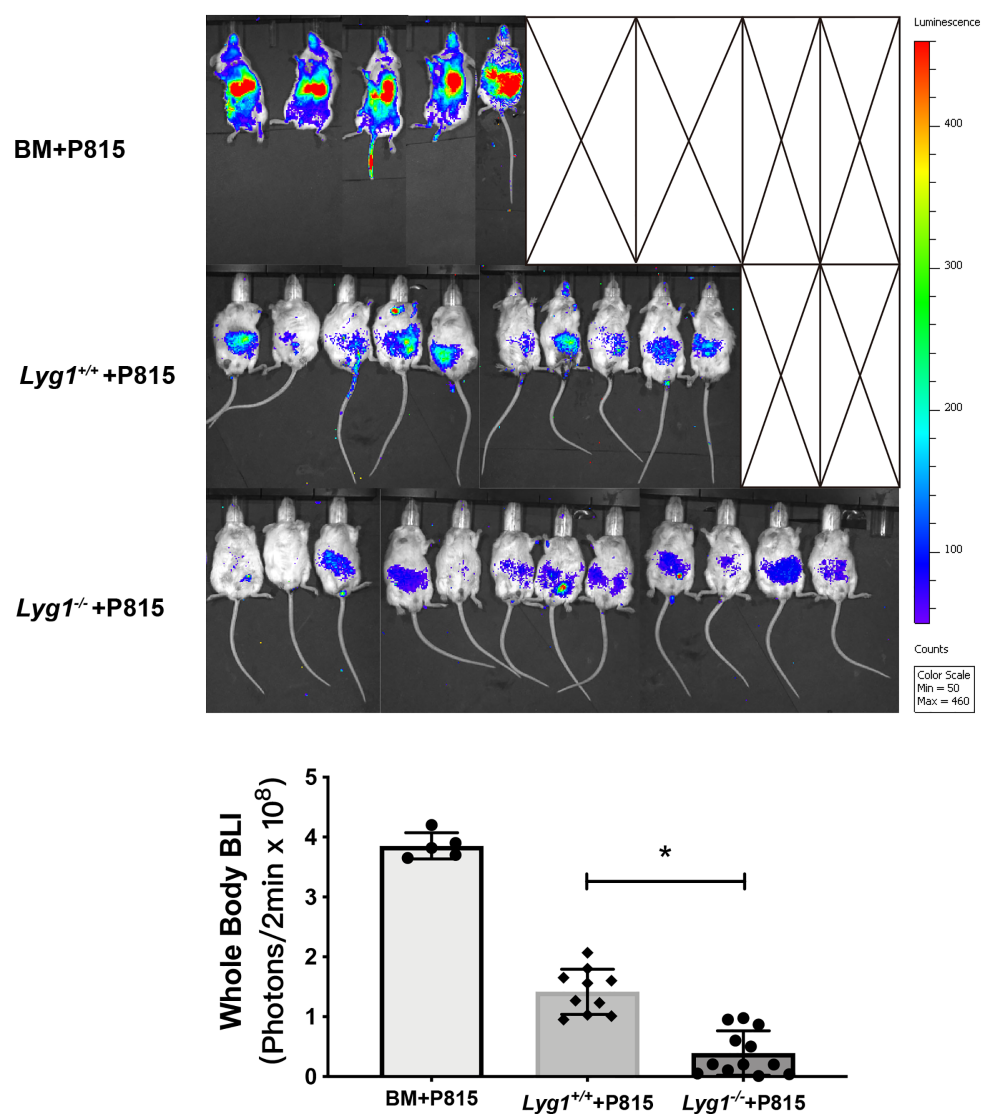

FIGURE 8 | LYG1 deficiency in donor T cells preserved GVT response. Lethally irradiated BALB/c mice were reconstituted with $5 \times 10^{6}$ B6 BM with or without $3 \times$ $10^{6} \mathrm{~T}$ cells from $\mathrm{Lyg} 1^{+/+}$or $L y g 1^{-/}$mice, followed by $2.5 \times 10^{4} \mathrm{P} 815$ cells $(\mathrm{H} 2 \mathrm{Kd}$ ) injected intravenously. (A) Survival after transplantation was monitored. (B) Tumor growth was monitored using bioluminescence imaging on day 14. Bioluminescence was quantified using whole body with Living Image software. Whole body images are shown and statistical results of average bioluminescence intensities are expressed as the mean $\pm \mathrm{SD}$, ${ }^{*} \mathrm{p}<0.05 \mathrm{compared}$ with $L y g 1^{+/+}$group. (C) Livers were excised when the mice died or on day 14 after transplantation. $\mathrm{n}=12$ for $\operatorname{Lyg} 1^{+/+}$or $L y g 1^{-/-}$mice group, $\mathrm{n}=10$ for BM group. * $\mathrm{p}<0.05$ compared with $L y g 1^{+/+}$group.

pathway related with CXCL10-CXCR3 axis, which was consistent with this report (35).

As a secretory protein, the cell sources of LYG1 are unclear. In this study, we demonstrated the role of LYG1 in aGVHD using WT BM and $L y g 1^{+/+}$or $L y g 1^{-/-}$T cells as the graft, but not $\mathrm{KO} \mathrm{BM}$ and $L y g 1^{+/+}$ or $L y g 1^{-/-} \mathrm{T}$ cells as the graft. Because only transplantation of allogeneic BM did not induce aGVHD, we excluded the effects of LYG1 derived from of BM in aGVHD mouse model we used in this study. Second, the recipients and its irradiation conditions of WT and
KO groups were all the same, so we excluded the impacts of LYG1 derived from recipients in aGVHD mouse model we used. More importantly, rhLYG1 aggravated the aGVHD severity by promoting IFN- $\gamma$ production and inhibiting Foxp3 expression, providing orthogonal validation for the results established using the $L y g 1^{-/-}$mice.

In summary, we demonstrate LYG1 regulates aGVHD via altering the alloreactivity of $\mathrm{CD}^{+} \mathrm{T}$ cells and the balance of Th1 and Treg differentiation of allogeneic $\mathrm{CD}^{+} \mathrm{T}$ cells. Our study indicates that LYG1 may be a novel target in 
aGVHD by mitigating aGVHD without impairing GVT effect. The therapeutic effect of targeting LYG1 is required in future investigations.

\section{DATA AVAILABILITY STATEMENT}

The original contributions presented in the study are included in the article/Supplementary Material. Further inquiries can be directed to the corresponding authors.

\section{ETHICS STATEMENT}

The animal study was reviewed and approved by Ethics Committee of Peking University First Hospital. Written informed consent was obtained from the owners for the participation of their animals in this study.

\section{AUTHOR CONTRIBUTIONS}

HL contributed conception and design of the study, performed the most experiments of this study and wrote the paper. ZY performed the MLR assay and part of aGVHD models. BT, SM, and CQ helped to establish aGVHD mouse models. YL, ZL, YS, and YZ performed part of flow cytometric analysis. QW, MY, and ZS performed part of qPCR experiments. HR and YD contributed conception and design of the study. All authors contributed to the article and approved the submitted version.

\section{FUNDING}

This study was supported by grant from The National Natural Science Foundation of China (NSFC) (Grant Number 81600144, 82071757 and 81970160) and grant from Beijing Natural Science Foundation (Grant Number 7212115).

\section{REFERENCES}

1. Holtan SG, Pasquini M, Weisdorf DJ. Acute Graft-Versus-Host Disease: A Bench-To-Bedside Update. Blood (2014) 124(3):363-73. doi: 10.1182/blood2014-01-514786

2. Ferrara JL, Levine JE, Reddy P, Holler E. Graft-Versus-Host Disease. Lancet (London England) (2009) 373(9674):1550-61. doi: 10.1016/s0140-6736(09) 60237-3

3. Blazar BR, Murphy WJ, Abedi M. Advances in Graft-Versus-Host Disease Biology and Therapy. Nat Rev Immunol (2012) 12(6):443-58. doi: 10.1038/ nri3212

4. Ichiki Y, Bowlus CL, Shimoda S, Ishibashi H, Vierling JM, Gershwin ME. T Cell Immunity and Graft-Versus-Host Disease (GVHD). Autoimmun Rev (2006) 5(1):1-9. doi: 10.1016/j.autrev.2005.02.006

5. Magenau J, Reddy P. Next Generation Treatment of Acute Graft-Versus-Host Disease. Leukemia (2014) 28(12):2283-91. doi: 10.1038/leu.2014.195

6. Henden AS, Hill GR. Cytokines in Graft-Versus-Host Disease. J Immunol (2015) 194(10):4604-12. doi: 10.4049/jimmunol.1500117

\section{ACKNOWLEDGMENTS}

The authors would like to thank Prof. Wenling Han for insightful suggestions and providing Lyg1/-- mice and LYG1-expressing vector at Peking University Health Science Center (Beijing, China).

\section{SUPPLEMENTARY MATERIAL}

The Supplementary Material for this article can be found online at: https://www.frontiersin.org/articles/10.3389/fimmu.2021.647894/ full\#supplementary-material

Supplementary Figure 1 | Gating strategies for flow cytometry analyses presented in Figure 1. (A-C) The expression of CD69 (A), IFN- $\gamma$ (B) and Foxp3 (C) in isotype (ISO) (left) and negative control without stimulating cells (right).

Supplementary Figure 2 | Gating strategies for flow cytometry analyses in T cells before adoptive transfer presented in Figure $\mathbf{2}(\mathbf{A})$. (B, C) Representative flow cytometry plots and frequencies of naive $\left(\mathrm{CD} 44^{\mathrm{lo}} \mathrm{CD} 62 \mathrm{~L}^{\mathrm{hi}}\right)$, central memory (CD44 ${ }^{\text {hi }} \mathrm{CD62} \mathrm{L}^{\text {hi}}$ ), effector (CD44 ${ }^{\text {hi }} \mathrm{CD} 2 \mathrm{~L}^{\text {lo }}$ ) in $\mathrm{CD}^{+} \mathrm{T}$ cells and $\mathrm{CD} 8^{+} \mathrm{T}$ cells respectively. $n=5$ per group. (D, E) The percentages of $C D 3^{+} T, C D 4^{+} T$ and $C D 8^{+} T$ cells in BM cells from donor mice before adoptive transfer.

Supplementary Figure 3 | LYG1 deficiency reduced allogeneic T cells function in haploidentical transplant model. Splenocytes of recipient mice were isolated on day 14 after transplantation and analyzed by flow cytometry. (A, B) The percentages of CD69 expression in $\mathrm{CD}^{+} \mathrm{T}$ cells and $\mathrm{CD}^{+} \mathrm{T}$ cells. $(\mathbf{C}, \mathbf{D})$ The percentages of IFN- $\gamma$ expression in $\mathrm{CD}^{+}{ }^{+} \mathrm{T}$ cells and $\mathrm{CD}^{+} \mathrm{T}$ cells. (E, F) The percentages of Foxp3 expression in $\mathrm{CD}^{+} \mathrm{T}$ cells and $\mathrm{CD} 8^{+} \mathrm{T}$ cells. $\mathrm{n}=5$ per group.

Supplementary Figure 4 | Gating strategies for flow cytometry analyses presented in Figure 3. The expression of CD69 (A, B), CD44 and CD62L (C, D), IFN- $\gamma(\mathbf{E}, \mathbf{F})$ and Foxp3 $(\mathbf{G}, \mathbf{H})$ in $\mathrm{CD}^{+} \mathrm{T}$ cells and $\mathrm{CD} 8^{+} \mathrm{T}$ cells respectively in ISO (left), BM control (middle) and Syn control (right).

Supplementary Figure 5 | The concentrations of IFN- $\gamma$, TNF- $\alpha$ and IL-6 in serum in aGVHD models. (A)The concentrations of IFN- $\gamma$, TNF- $\alpha$ and IL- 6 in serum at day 7 after transplantation in major MHC mismatched aGVHD model. (B)The concentrations of IFN- $\gamma$, TNF- $\alpha$ and IL- 6 in serum at day 14 after transplantation in haploidentical model. (C, D) The concentrations of IFN- $\gamma$, TNF- $\alpha$ and IL- 6 in serum at day 7 after transplantation in purified $C D 4^{+} T$ cells or $C D 8^{+} T$ cells. $n=4-5$ per group. Statistical results are expressed as the mean $\pm \mathrm{SD},{ }^{*} \mathrm{p}<0.05$ compared with Lyg $1^{+/+}$group.

7. Romano M, Tung SL, Smyth LA, Lombardi G. Treg Therapy in Transplantation: A General Overview. Transpl Int (2017) 30(8):745-53. doi: $10.1111 /$ tri.12909

8. Blazar BR, MacDonald KPA, Hill GR. Immune Regulatory Cell Infusion for Graft-Versus-Host Disease Prevention and Therapy. Blood (2018) 131 (24):2651-60. doi: 10.1182/blood-2017-11-785865

9. Elias S, Rudensky AY. Therapeutic Use of Regulatory T Cells for GraftVersus-Host Disease. Br J Haematol (2019) 187(1):25-38. doi: 10.1111/ bjh.16157

10. Choi SW, Reddy P. Current and Emerging Strategies for the Prevention of Graft-Versus-Host Disease. Nat Rev Clin Oncol (2014) 11(9):536-47. doi: 10.1038/nrclinonc.2014.102

11. Liu H, Zhang Y, Liu Z, Wang P, Mo X, Fu W, et al. LYG1 Exerts Antitumor Function Through Promoting the Activation, Proliferation, and Function of CD4(+) T Cells. Oncoimmunology (2017) 6(4):e1292195. doi: 10.1080/ 2162402X.2017.1292195

12. Bader CS, Barreras H, Lightbourn CO, Copsel SN, Wolf D, Meng J, et al. STING Differentially Regulates Experimental GVHD Mediated by CD8 
Versus CD4 T Cell Subsets. Sci Transl Med (2020) 12(552):eaay5006. doi: $10.1126 /$ scitranslmed.aay5006

13. Zhang XH, Zhou Y, Zhang JM, Zhou SY, Wang M, Feng R, et al. IL-35 Inhibits Acute Graft-Versus-Host Disease in a Mouse Model. Int Immunopharmacol (2015) 29(2):383-92. doi: 10.1016/j.intimp.2015.10.025

14. Cooke KR, Kobzik L, Martin TR, Brewer J, Delmonte JJr., Crawford JM, et al. An Experimental Model of Idiopathic Pneumonia Syndrome After Bone Marrow Transplantation: I. The Roles of Minor H Antigens and Endotoxin. Blood (1996) 88(8):3230-9. doi: 10.1182/blood.V88.8.3230.bloodjournal8883230

15. Fukui J, Inaba M, Ueda Y, Miyake T, Hosaka N, Kwon AH, et al. Prevention of Graft-Versus-Host Disease by Intra-Bone Marrow Injection of Donor T Cells. Stem Cells (2007) 25(6):1595-601. doi: 10.1634/stemcells.2006-0234

16. Hill GR, Crawford JM, Cooke KR, Brinson YS, Pan L, Ferrara JL. Total Body Irradiation and Acute Graft-Versus-Host Disease: The Role of Gastrointestinal Damage and Inflammatory Cytokines. Blood (1997) 90 (8):3204-13. doi: 10.1182/blood.V90.8.3204

17. Edinger M, Hoffmann P, Ermann J, Drago K, Fathman CG, Strober S, et al. CD4+CD25+ Regulatory T Cells Preserve Graft-Versus-Tumor Activity While Inhibiting Graft-Versus-Host Disease After Bone Marrow Transplantation. Nat Med (2003) 9(9):1144-50. doi: 10.1038/nm915

18. Fu J, Wang D, Yu Y, Heinrichs J, Wu Y, Schutt S, et al. T-Bet is Critical for the Development of Acute Graft-Versus-Host Disease Through Controlling T Cell Differentiation and Function. J Immunol (2015) 194(1):388-97. doi: 10.4049/jimmunol.1401618

19. Ferreira LMR, Muller YD, Bluestone JA, Tang Q. Next-Generation Regulatory T Cell Therapy. Nat Rev Drug Discov (2019) 18(10):749-69. doi: 10.1038/ s41573-019-0041-4

20. Moy RH, Huffman AP, Richman LP, Crisalli L, Wang XK, Hoxie JA, et al. Clinical and Immunologic Impact of CCR5 Blockade in Graft-Versus-Host Disease Prophylaxis. Blood (2017) 129(7):906-16. doi: 10.1182/blood-2016-08-735076

21. He S, Cao Q, Qiu Y, Mi J, Zhang JZ, Jin M, et al. A New Approach to the Blocking of Alloreactive T Cell-Mediated Graft-Versus-Host Disease by In Vivo Administration of Anti-CXCR3 Neutralizing Antibody. J Immunol (2008) 181(11):7581-92. doi: 10.4049/jimmunol.181.11.7581

22. Sackstein R. A Revision of Billingham's Tenets: The Central Role of Lymphocyte Migration in Acute Graft-Versus-Host Disease. Biol Blood Marrow Transplant (2006) 12(1 Suppl 1):2-8. doi: 10.1016/j.bbmt.2005.09.015

23. Lu Y, Waller EK. Dichotomous Role of Interferon-Gamma in Allogeneic Bone Marrow Transplant. Biol Blood Marrow Transplant (2009) 15(11):1347-53. doi: 10.1016/j.bbmt.2009.07.015

24. Kappel LW, Goldberg GL, King CG, Suh DY, Smith OM, Ligh C, et al. Il-17 Contributes to CD4-Mediated Graft-Versus-Host Disease. Blood (2009) 113 (4):945-52. doi: 10.1182/blood-2008-08-172155

25. Wang H, Yang YG. The Complex and Central Role of Interferon- $\gamma$ in GraftVersus-Host Disease and Graft-Versus-Tumor Activity. Immunol Rev (2014) 258(1):30-44. doi: 10.1111/imr.12151

26. Dey BR, Yang YG, Szot GL, Pearson DA, Sykes M. Interleukin-12 Inhibits Graft-Versus-Host Disease Through an Fas-mediated Mechanism Associated
With Alterations in Donor T-cell Activation and Expansion. Blood (1998) 91 (9):3315-22. doi: 10.1182/blood.V91.9.3315

27. Reddy P, Teshima T, Kukuruga M, Ordemann R, Liu C, Lowler K, et al. Interleukin-18 Regulates Acute Graft-Versus-Host Disease by Enhancing Fasmediated Donor T Cell Apoptosis. J Exp Med (2001) 194(10):1433-40. doi: $10.1084 /$ jem.194.10.1433

28. Vignali DA, Collison LW, Workman CJ. How Regulatory T Cells Work. Nat Rev Immunol (2008) 8(7):523-32. doi: 10.1038/nri2343

29. Edinger M. Regulatory T Cells for the Prevention of Graft-Versus-Host Disease: Professionals Defeat Amateurs. Eur J Immunol (2009) 39 (11):2966-8. doi: 10.1002/eji.200940030

30. Robb RJ, Lineburg KE, Kuns RD, Wilson YA, Raffelt NC, Olver SD, et al. Identification and Expansion of Highly Suppressive CD8(+)FoxP3(+) Regulatory T Cells After Experimental Allogeneic Bone Marrow Transplantation. Blood (2012) 119(24):5898-908. doi: 10.1182/blood-201112-396119

31. Zheng J, Liu Y, Liu Y, Liu M, Xiang Z, Lam KT, et al. Human CD8+ Regulatory T Cells Inhibit GVHD and Preserve General Immunity in Humanized Mice. Sci Transl Med (2013) 5(168):168ra9. doi: 10.1126/ scitranslmed.3004943

32. Fasching P, Stradner M, Graninger W, Dejaco C, Fessler J. Therapeutic Potential of Targeting the Th17/Treg Axis in Autoimmune Disorders. Molecules (2017) 22(1):134. doi: 10.3390/molecules22010134

33. Ehrenstein MR, Evans JG, Singh A, Moore S, Warnes G, Isenberg DA, et al. Compromised Function of Regulatory T Cells in Rheumatoid Arthritis and Reversal by anti-TNFalpha Therapy. J Exp Med (2004) 200(3):277-85. doi: 10.1084/jem.20040165

34. Aravena O, Pesce B, Soto L, Orrego N, Sabugo F, Wurmann P, et al. Anti-TNF Therapy in Patients With Rheumatoid Arthritis Decreases Th1 and Th17 Cell Populations and Expands IFN- $\gamma$-Producing NK Cell and Regulatory T Cell Subsets. Immunobiology (2011) 216(12):1256-63. doi: 10.1016/j.imbio. 2011.07.006

35. Zohar Y, Wildbaum G, Novak R, Salzman AL, Thelen M, Alon R, et al. CXCL11-Dependent Induction of FOXP3-negative Regulatory T Cells Suppresses Autoimmune Encephalomyelitis. J Clin Invest (2014) 124 (5):2009-22. doi: 10.1172/jci71951

Conflict of Interest: The authors declare that the research was conducted in the absence of any commercial or financial relationships that could be construed as a potential conflict of interest.

Copyright $\odot 2021$ Liu, Yu, Tang, Miao, Qin, Li, Liang, Shi, Zhang, Wang, Yan, Song, Ren and Dong. This is an open-access article distributed under the terms of the Creative Commons Attribution License (CC BY). The use, distribution or reproduction in other forums is permitted, provided the original author(s) and the copyright owner(s) are credited and that the original publication in this journal is cited, in accordance with accepted academic practice. No use, distribution or reproduction is permitted which does not comply with these terms. 